\title{
EFFECT OF SHOCK WAVES ON SUSPENDED AND IMMOBILIZED L1210 CELLS
}

\author{
Franz BrÚmMER, JoACHIM BRENNER, THOMAS BRÄUNER and DiETER F. HÜlSER \\ Biology Institute, Biophysics Department, University of Stuttgart, Pfaffenwaldring 577000 Stuttgart 80, \\ Federal Republic of Germany
}

(Received 21 June 1988; in final form 20 September 1988)

\begin{abstract}
L1210 mouse leukemia cells have been exposed to different doses of shock waves generated by underwater spark discharge at $18 \mathrm{kV}$ in an experimental lithotripter (XL1, Dornier). Histological and flow cytometric investigations revealed severe damage and a $L_{50}$ of about 420 shock waves when the cells were treated as suspensions. Cells immobilized in gelatine, however, were unaffected, indicating that secondary effects are responsible for the cellular damage. Possible mechanisms such as cavitation, jets, and shear forces are discussed.
\end{abstract}

Key Words: Shock waves, Extracorporal shock wave lithotripsy, L1210 tumor cells, Cavitation, Jets, Shear forces, Immobilization, Cell suspension, Flow cytometry, Cell culture, Histology.

\section{INTRODUCTION}

Focused acoustic shock waves have recently been introduced as an energy source for a variety of medical applications. Extracorporally generated shock waves allow for the nonsurgical disintegration of kidney stones; the first routine instrument was the HM3 (Dornier Medical Systems GmbH, Germering, FRG; Chaussy et al. 1982). This extracorporal shock wave lithotripter uses water as the acoustic coupling medium for shock waves generated by an underwater spark discharge between two electrode tips, located in the first focal point (F1 = discharge focus) of a semiellipsoid. The energy of the shock wave is concentrated in the second focal point (F2 = target focus) of the semi-ellipsoid where the target (e.g., kidney stone) is positioned (Fig. 1). Worldwide more than one million patients have been successfully treated with this nonsurgical therapy for the removal of renal and ureteral calculi (Eisenberger 1988) and ESWL is now also in clinical use for the fragmentation of gall stones (Brendel and Enders 1983; Sauerbruch et al. 1986; Delius 1987). In addition to this underwater electrode system other principles of the generation of shock waves have been modified for medical application (Eisenberger and Rassweiler 1986).

Prior to the clinical shock wave application, Chaussy et al. (1986c) performed extensive studies on the pathophysiological effects of a shock wave expo- sure on various organs in animals. While in vitro treated red blood cells were damaged, no evidence of hemolysis, however, was observed after in vivo experiments. Clinically no changes in blood chemistry could be detected. Studying the acute effects of ESWL on renal function Kaude et al. (1985) observed no significant reduction of total effective renal plasma flow using quantitative radionuclide renography. In the treated kidney, however, renal plasma flow decreased by more than $5 \%$ in $30 \%$ of all cases. Magnetic resonance imaging revealed significant morphological changes in the treated kidney. Brendel et al. (1987) described a vasoconstriction of arteriolar microvascular segments after shock wave treatment. Biochemical investigations, including measurements of the release of cytoplasmatic enzymes in blood and urine of shock-wave-exposed patients, showed signifcant hemolysis and myolysis as well as pathological alteration of the treated kidneys (Kishimoto et al. 1986). Similar results were obtained by Delius and coworkers (1988), who observed haematomas and diffuse interstitial haemorrhage in shock-wavetreated canine kidneys. Quite recently it has been reported that shock waves affect viability and growth of tumor cells (Russo et al. 1986, 1987), indicating that tumor treatment could be another application for shock waves.

Our investigations were performed in order to detect and characterize biological effects of shock 


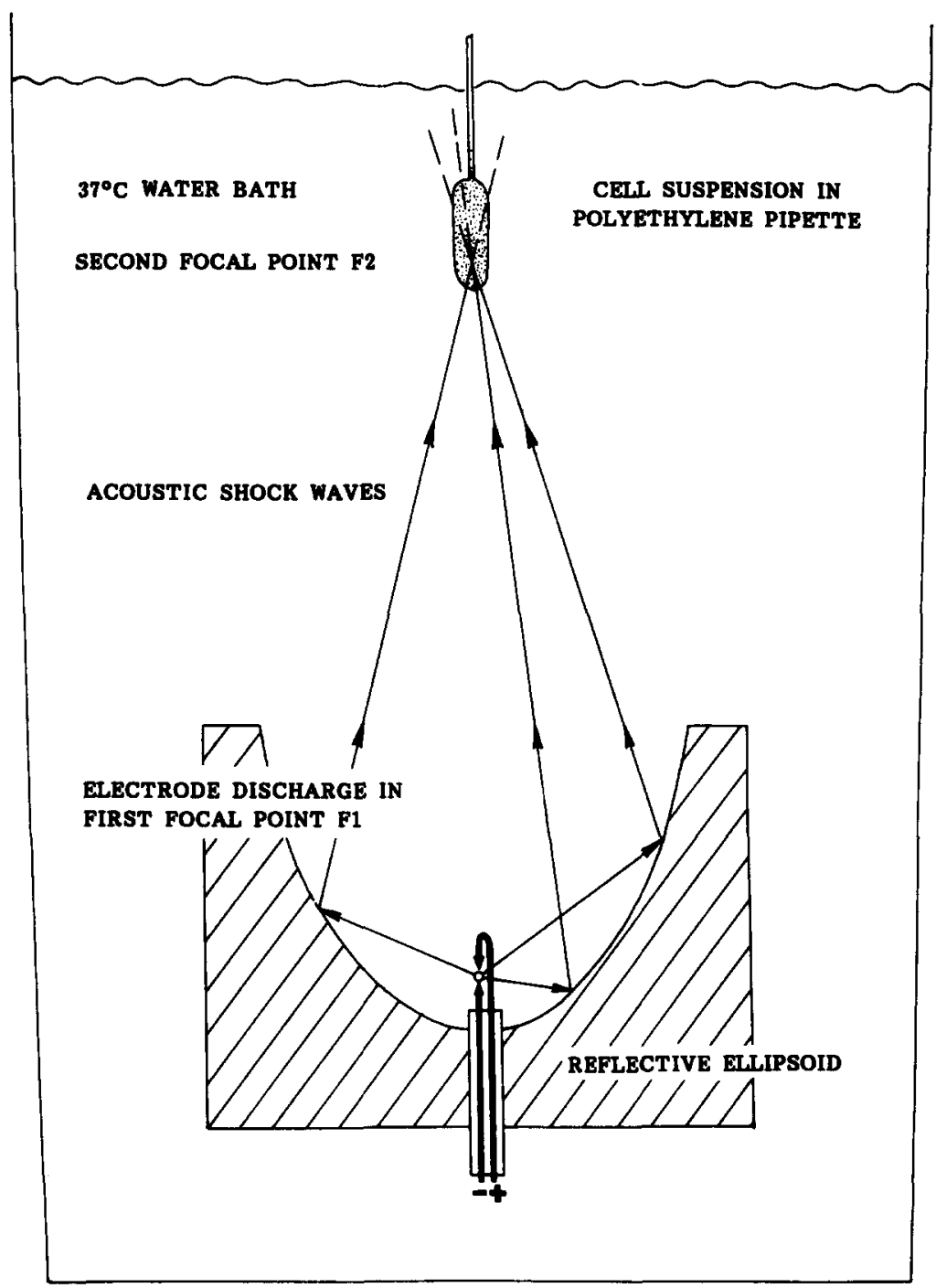

Fig. 1. Experimental setup illustrating the electrode for generating underwater spark discharge in the focal point (F1) of a brass ellipsoid. The reflected shock waves are concentrated in the second focal point (F2), where the cells are positioned in a polyethylene pipette.

waves on L1210 mouse leukemia cells. These cells were severely damaged when treated as suspensions but survived almost unaffected when immobilized in gelatine during the shock wave application. A preliminary report of our results has been published (Brümmer et al. 1988).

\section{MATERIAL AND METHODS}

\section{Cell culture}

L1210 cells, a lymphocytic mouse leukemia cell line (Hutchinson et al. 1966), were maintained as suspensions at $37^{\circ} \mathrm{C}$ under an atmosphere of $5 \% \mathrm{CO}_{2}$ in air at $\mathrm{pH}$ 7.4. They were grown in tissue culture flasks (Greiner, Nürtingen, FRG) filled with RPMI
1640 medium with $\mathrm{NaHCO}_{3}$ (Boehringer Mannheim 209945, FRG) and supplemented with $15 \%$ fetal calf serum (Boehringer Mannheim 210471). Prior to use, $100 \mu \mathrm{l} \mathrm{mercaptoethanol}(0.4 \mathrm{mg} / \mathrm{ml})$ and $2 \mathrm{ml}$ sodiumpyruvate $(1 \mathrm{mg} / \mathrm{ml})$ were added to $100 \mathrm{ml}$ RPMI 1640 medium. Cell cultures were routinely tested for mycoplasma contamination according to the technique described by Chen (1977).

\section{Shock wave treatment}

For treatment with shock waves the cells were pelleted by centrifugation $(10 \mathrm{~s}, 1000 \mathrm{~g})$ and resuspended in culture medium to a final cell concentration of about $2 \times 10^{5}$ cells per $\mathrm{ml}$. The concentration of intact cells was determined before and after shock wave treatment with a Coulter Counter (Model In- 
dustrial D, Coulter Electronics, Hialeah, FL, USA). Single cell suspensions were transferred into polyethylene pipettes $(3.5 \mathrm{ml}$, diameter $1.3 \mathrm{~cm}$; Renner GmbH, Darmstadt, FRG). The cells in the pipette ball were submerged in the $37^{\circ} \mathrm{C}$ waterbath of a XL1 lithotripter (Dornier) and positioned into the target focus of the brass ellipsoid indicated by two crossing laser beams (Fig. 1).

For shock wave treatment of immobilized cells, suspensions were pelleted by centrifugation $(10 \mathrm{~s}$, $1000 \mathrm{~g}$ ) and resuspended in $1 \mathrm{ml}$ RPMI $+15 \%$ serum at $37^{\circ} \mathrm{C}$. This concentrated cell suspension was mixed with $4 \mathrm{ml}$ of a $15 \%$ solution of purified gelatine (Merck, Darmstadt, FRG) in normal growth medium (Wilton-Smith 1983). The mixture was quickly polymerized in a waterbath at $4^{\circ} \mathrm{C}$ and treated with shock waves at $21^{\circ} \mathrm{C}$. The cells were recovered by liquefying the gel at $37^{\circ} \mathrm{C}$.

Shock waves were generated by underwater spark discharge $(18 \mathrm{kV}, 80 \mathrm{nF})$ at a frequency of $1 \mathrm{~Hz}$. The XL1 lithotripter is an experimental instrument with a HM3 generator. For the Dornier HM3 lithotripter shock wave pressures of up to $38.6 \mathrm{MPa}$ have been measured in the focus at $20 \mathrm{kV}$ discharge potential (Coleman et al. 1987a). The pressure decreases symmetrically to $50 \%$ within $10 \mathrm{~mm}$ in the plane perpendicular to the major axis and within $60 \mathrm{~mm}$ along the major axis (Saunders and Coleman 1987). In the experimental XL1-lithotripter the pressure is about $2 \times$ higher (Dornier Medizintechnik, personal communication). Cells were treated with different numbers of shock waves as indicated in the result section. Controls were placed in a water bath at $37^{\circ} \mathrm{C}$ for the time necessary for the shock wave treatment. For the experiments electrodes were not used prior to the first 50 and after 1500 ignitions.

Water in the lithotripter was partially degassed by a vacuum pump (Maprotec $\mathrm{GmbH}$, Idstein, FRG). Oxygen concentration was determined with the Aquamerck Oxygen test kit (Merck 11149, Darmstadt) based on the Winkler titration.

For the visualization of shock wave impacts, Dornier standard platter blocks $(3.0 \times 3.0 \times 1.5 \mathrm{~cm})$, a mixture of dental cement, and glass microspheres, were positioned in the target focus and exposed to 125 shock waves in normal and partially degassed water.

\section{Histology}

Pelleted cells were fixed in $2.5 \%$ glutaraldehyde (Merck 4239) in 0.1 M PBS at pH 7.1 for $2 \mathrm{~h}$ at room temperature. After five buffer rinses in 0.1 M PBS, cells were additionally fixed in $1 \%$ osmium tetroxide in $0.1 \mathrm{M} \mathrm{PBS}$ for $1 \mathrm{~h}$ at room temperature. They were again rinsed $5 \times$ in buffer and dehydrated $(7 \mathrm{~min}$ in $40,50,60,70$, and $80 \%$ ethanol, $2 \times 15 \mathrm{~min}$ in 96 and $100 \%$ ethanol and $2 \times 15 \mathrm{~min}$ in propylene oxide). Cells were impregnated over night in $2: 1$ and $1: 1$ mixtures of propylene oxide and the epoxy resin glycidether 100 (formerly Epon 812, C. Roth, Karlsruhe, FRG), followed by pure epoxy resin, and polymerized for $12 \mathrm{~h}$ at $40^{\circ} \mathrm{C}$ and $48 \mathrm{~h}$ at $70^{\circ} \mathrm{C}$. Then $1-\mu \mathrm{m}$ sections were cut with glass knives in an ultramicrotome (OM U3, Reichert, Wien, Austria) and stained according to Richardson et al. (1960).

Viability was evaluated using the trypan blue dye exclusion test (Phillips 1973). For staining $0.5 \mathrm{ml}$ trypan blue dye (T-9520, Sigma Chemical Co., St. Louis, MO, USA) and $0.3 \mathrm{ml}$ PBS without $\mathrm{Ca}^{2+}$ and $\mathrm{Mg}^{2+}$ ( $\mathrm{pH} \mathrm{7.4)} \mathrm{were} \mathrm{added} \mathrm{to} 0.2 \mathrm{ml}$ of the cell suspension. A drop of the suspension was placed in a hemocytometer and viability was determined after 3 min. Results were expressed as the percentage of viability, defined by the proportion of stained cells with respect to the total cells counted.

\section{Flow cytometry}

With a double staining technique, damaged cells - characterized by the uptake of propidium iodide (PI, P-5264 Sigma; Krishan 1975; Sasaki et al. 1987) - could be discriminated from vital cells which were identified by hydrolized fluorescein diacetate (FDA, F-7378 Sigma; Rotman and Papermaster 1966). Each $3 \mathrm{ml}$ of control and shock-wave-treated cell suspensions were stained with both $30 \mu$ l of a PI stock solution $(2 \mathrm{mg} / \mathrm{ml}$ in distilled water) and $30 \mu \mathrm{l}$ of a FDA stock solution $(20.8 \mu \mathrm{g} / \mathrm{ml}$ in acetone). After a dye accumulation period of 2-3 min cell suspensions were analysed by flow cytometry.

The cell volume (VOL) was measured according to the Coulter principle (Coulter 1956), the green fluorescence of hydrolized FDA $(530 \pm 30 \mathrm{~nm})$ and the red fluorescence of PI ( $595 \pm 63 \mathrm{~nm})$ were simultaneously detected for each cell in a FACS-Analyzer (Becton Dickinson, Mountainview, CA, USA). Fluorescence was excited by a high-pressure mercury arc lamp. The orifice with a diameter of $150 \mu \mathrm{m}$ was operated at a constant current of $1 \mathrm{~mA}$. Ultracount (Becton Dickinson) was used as sheath fluid. For each histogram data from $10^{4}$ cells were stored and analyzed in a HP 9133 computer (Hewlett-Packard Company, Fort Collins, CO, USA) with the Consort 30 version $\mathrm{E}$ software (Becton Dickinson).

\section{Statistics}

The data are presented as means with standard deviations (S.D., Table 1) or as means with standard 
Table 1. Comparison of trypan blue staining with PIstaining of $\mathrm{L} 1210$ cells after shock wave treatment

\begin{tabular}{ccc}
\hline $\begin{array}{c}\text { Number of } \\
\text { shock } \\
\text { waves }\end{array}$ & $\begin{array}{c}\text { Trypan blue } \\
\text { stained cells \% } \\
\text { mean } \pm \text { S.D. }\end{array}$ & $\begin{array}{c}\text { PI-stained } \\
\text { cells \% } \\
\text { mean } \pm \text { S.D. }\end{array}$ \\
\hline $\begin{array}{c}\text { Control } \\
63\end{array}$ & $4.37 \pm 4.66$ & i.02 \pm 0.46 \\
125 & $3.43 \pm 4.86$ & n.d. \\
250 & $7.85 \pm 1.34$ & $7.20 \pm 2.79$ \\
375 & $27.66 \pm 20.08$ & $9.66 \pm 2.54$ \\
500 & $19.66 \pm 1.15$ & n.d. \\
750 & $15.57 \pm 9.62$ & $20.73 \pm 4.96$ \\
1000 & $23.10 \pm 10.89$ & $16.63 \pm 4.84$ \\
n.d. & $21.93 \pm 4.29$ \\
\hline
\end{tabular}

n.d. = not determined.

errors of the means (S.E.) (Figs. 3 and 5). Significance was tested using the Mann-Whitney U-test (Lienert 1973; Lorenz 1984). An error probability (p-value) $\leq 0.10$ was considered to indicate a significant difference. Exponential regression analyses were performed with Temple Datatap Analysis software (James Associates, Fort Collins, CO, USA) on a HP 9000 series 200 computer (Hewlett-Packard).

\section{RESULTS}

The influence of different gas concentrations in the lithotripter water bath on shock wave effects was investigated with standard platter blocks as well as L1210 cells in normal and partially degassed water. After degassing the water the oxygen concentration decreased from $9.19 \pm 0.16 \mathrm{mg} / \mathrm{l}(n=5)$ to 3.86

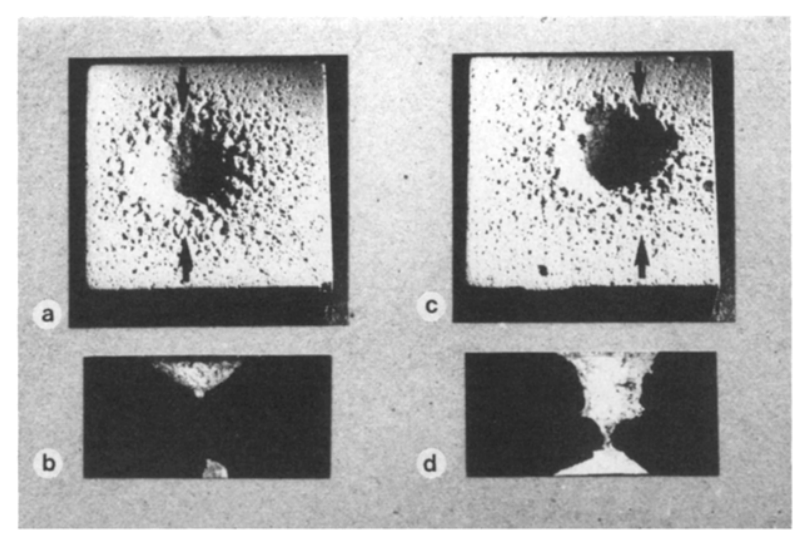

Fig. 2. Artificial stones (platter blocks) exposed to 125 shock waves in tap water (a, b) and partially degassed tap water (c, d). a, c: areal views, illuminated from the right side. $b, d$ : cross sections through the center of the craters as indicated by the arrows. For better visibility of the craters the sectioned area of the platter blocks was blackened. $\pm 0.28 \mathrm{mg} / \mathrm{l}(n=5)$. The standard platter blocks were positioned in the target focus and treated with 125 shock waves, which led to the destruction of the blocks, demonstrated for these two different conditions in Fig. 2. In tap water a wide distribution of the impacts (Fig. 2a) and a flat crater is seen (Fig. 2b). In contrast, in partially degassed water a more concentrated focus (Fig. 2c) resulted in a deeper crater (Fig. 2d) and in a more distinct destruction of the opposite side of the shock wave entry.

L1210 cell suspensions were exposed to 125 and 250 shock waves in the target focus. After shock wave treatment the percentage of intact cells was lower in partially degassed than in normal water. The results after 125 and 250 shock waves are shown in Fig. 3. All further experiments were performed in partially degassed water. Light microscopic examination of semithin sections of untreated L1210 cells showed almost exclusively intact cells throughout the cell cycle (Fig. 4a), cells treated with 500 shock waves revealed a high amount of fragmented cells and cell debris (Fig. 4b).

To investigate a possible influence of the electrodes' condition after varying numbers of ignitions we exposed cells to 375 shock waves with electrodes of different age (50-425, 425-800, and 800-1175 ignitions) and determined the cells' integrity by flow cytometry (Fig. 5). This method analyses three different parameters, the cell volume of intact cells, the green fluorescence of viable cells stained with FDA, and the red fluorescence of dead cells stained with PI. No significant differences could be detected.

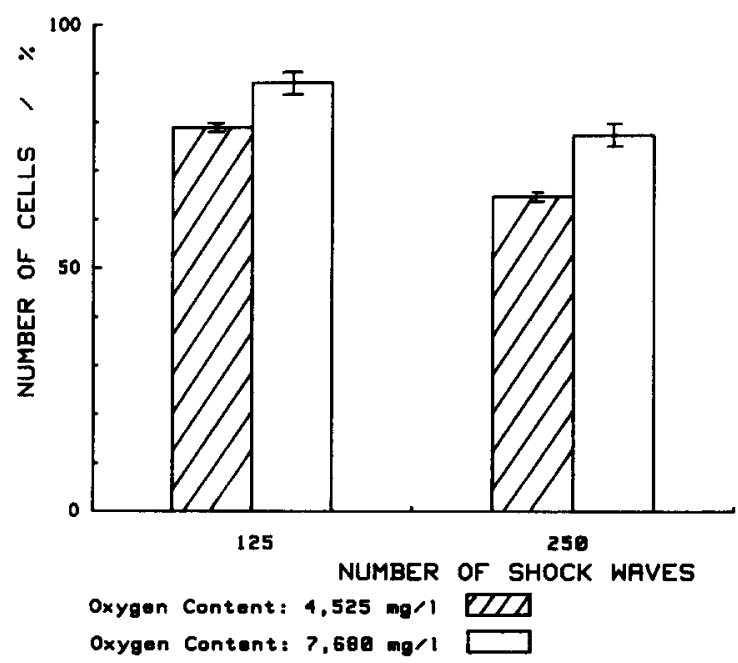

Fig. 3. Effect of normal and degassed water on shock wave treatment. Under both conditions the number of surviving cells differs significantly ( $p \leq 0.10$ ). 


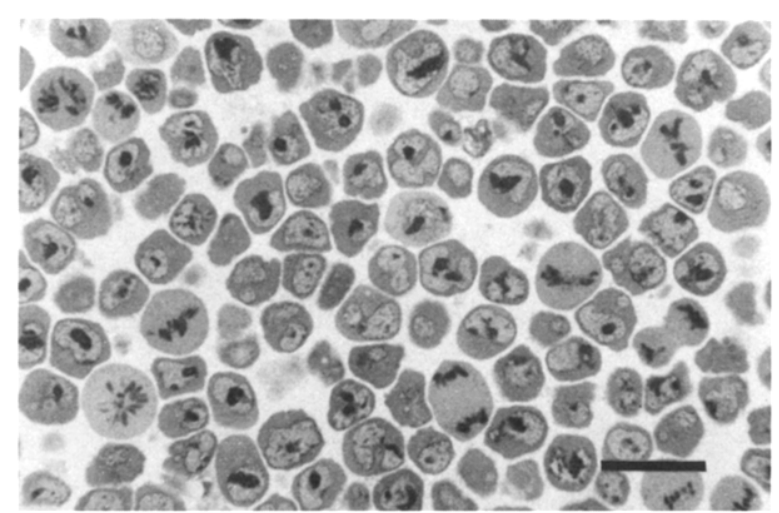

(a)

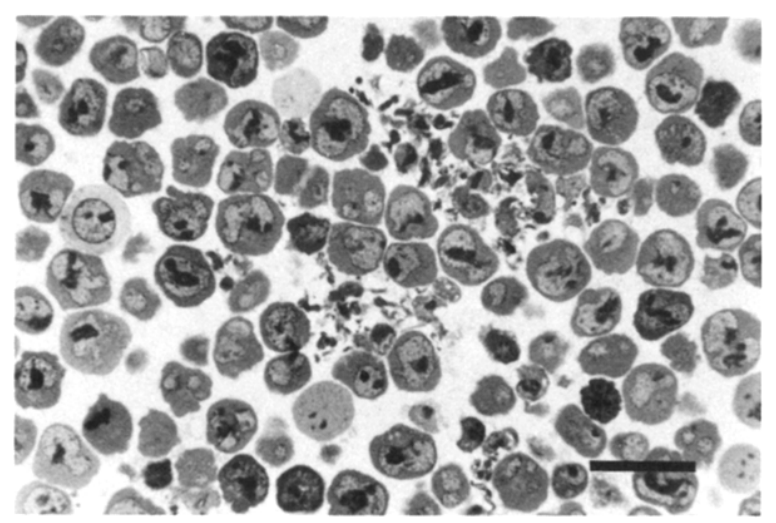

(b)

Fig. 4. Semithin sections of L1210 mouse leukemia cells. (a) control. (b) treated with 500 shock waves. Bar: $20 \mu \mathrm{m}$.
After exposure to 125 and 500 shock waves, cells were identified as intact by coulter counting and both control and treated cells were inoculated with the same concentration of intact cells for testing their proliferative capacity. They revealed no major differences in population doubling time as derived from the exponential growth phase, i.e., $620 \mathrm{~min}$ for each of the treated populations and 610 and $630 \mathrm{~min}$ for their controls (Figs. 6a and b). Shock-wave-treated cultures, however, exhibited a kind of lag phase which might be due to nonviable cells (see discussion).

Coulter Counter measurements of the total cell loss after shock wave treatment of suspended L1210 cells revealed a dose-dependent decrease in the proportion of intact cells (Fig. 7a, $\nabla$ ). Assuming that this is an exponential decrease $\left(N=N_{0} \cdot e^{-b x}\right)$, the regression analysis of these data revealed $N_{0}=98.2$ and $b$ $=1.36 \cdot 10^{-3}$ with a $\mathrm{LD}_{50}$ of 500 shock waves for intact cells. These populations of intact cells, however, contain subpopulations of nonviable cells as has been shown by trypan blue dye exclusion test (Table 1) and flow cytometry (Fig. 7a, $\diamond$ ).

This is illustrated with original measurements for five different shock wave doses in Fig. 8: the control culture shows distinct cell peaks in the VOLchannel as well as in the FDA-channel, only few cells were detected in the PI-channel. With increasing doses of shock waves the peak indicating intact cells

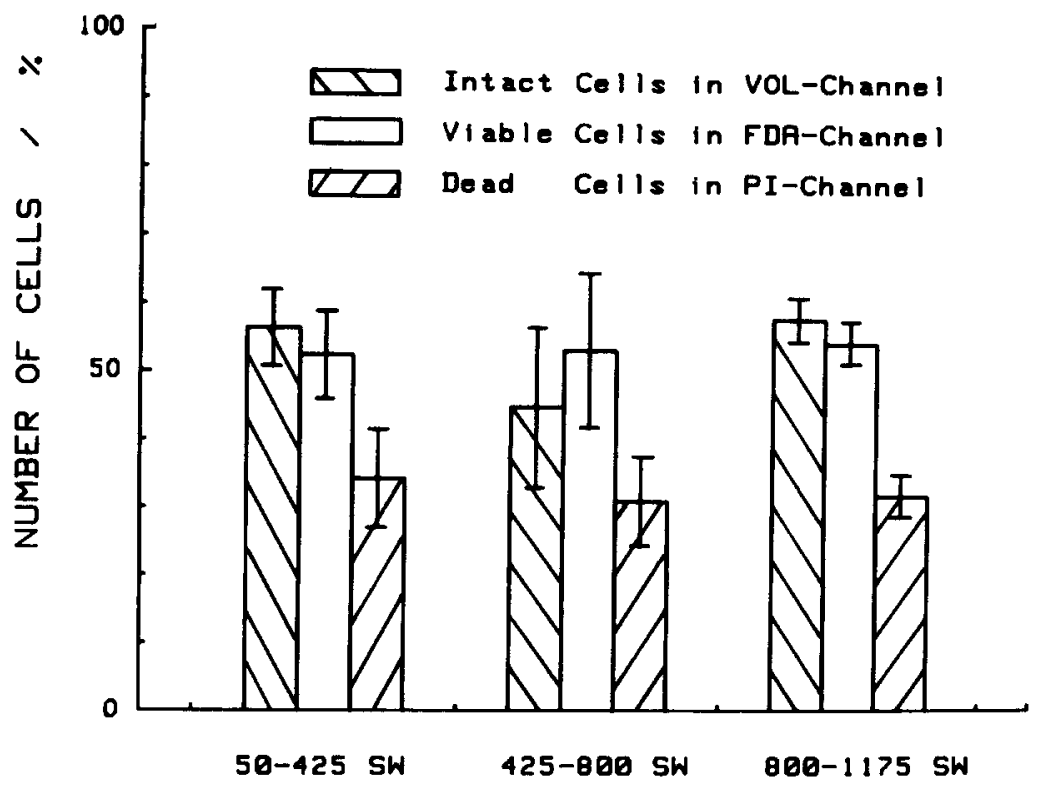

Fig. 5. Effect of electrode condition on cell survival. Cellular properties differ significantly only for $p \geq 0.50$ when L1210 mouse leukemia cells were exposed to 375 shock waves with electrodes of different age. 


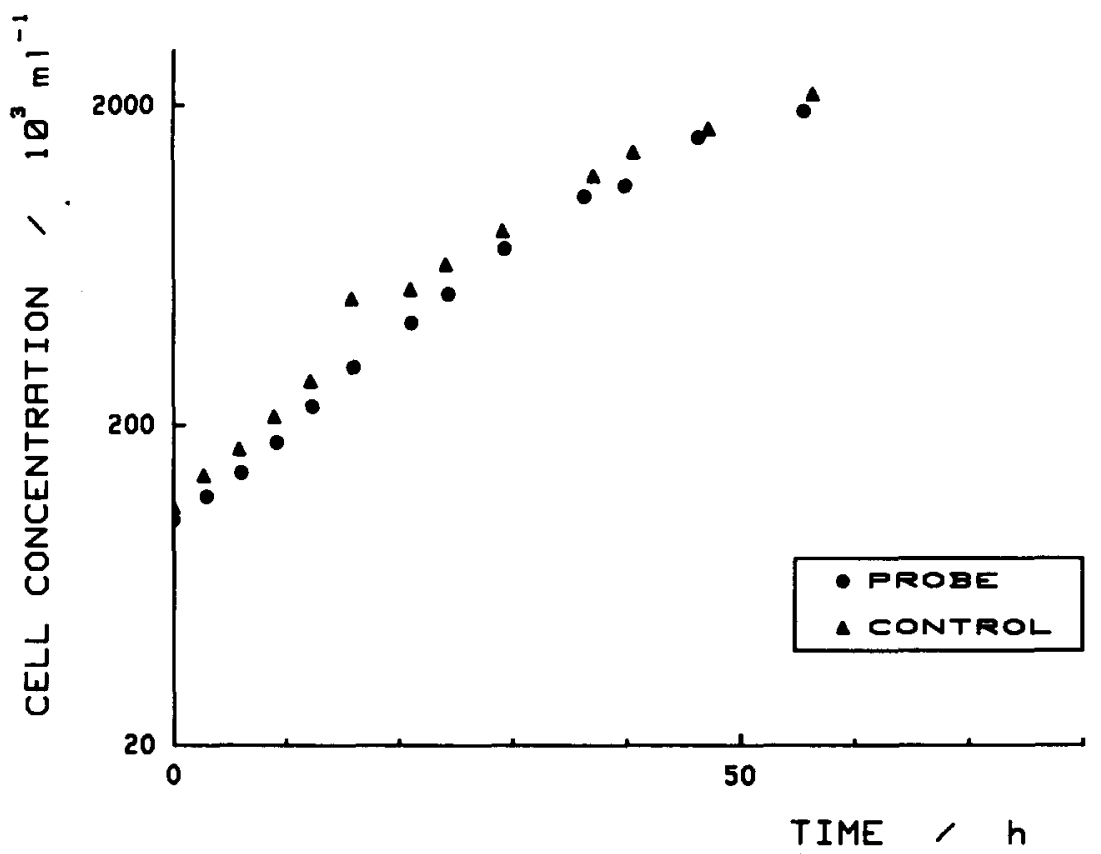

(a)

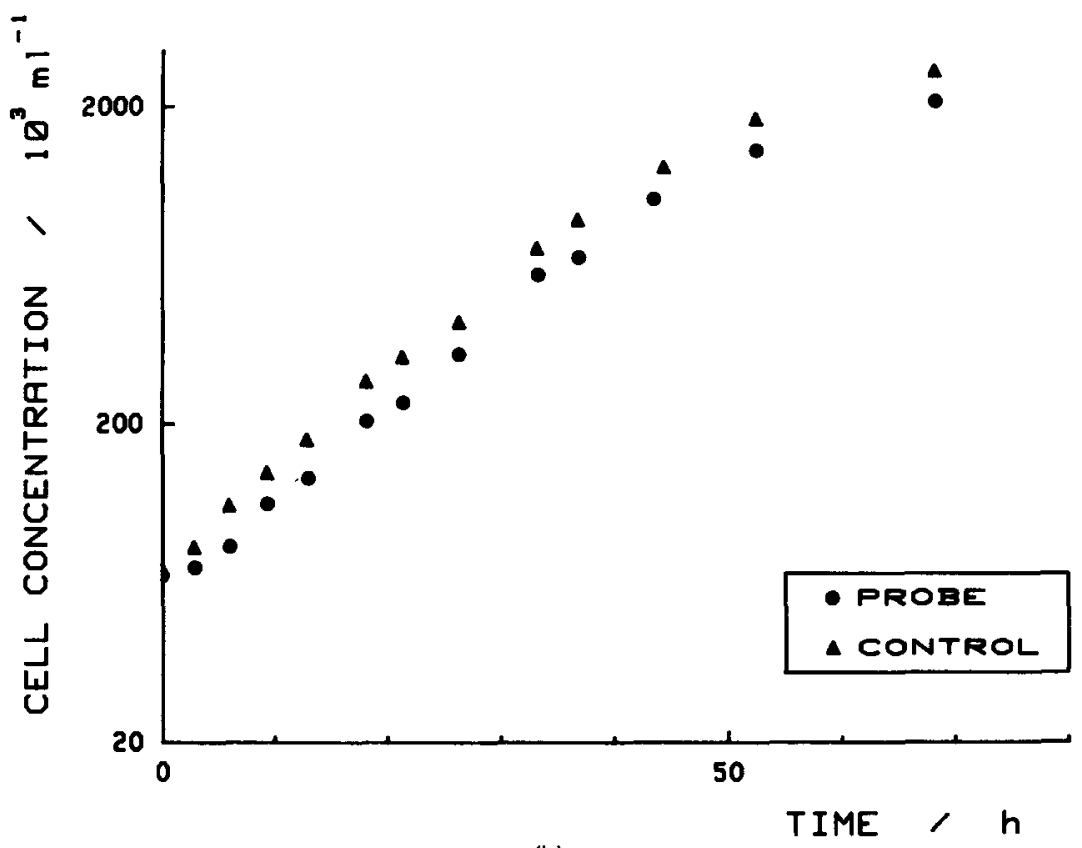

(b)

Fig. 6. Growth curve of L1210 mouse leukemia cells in suspension. (a) 125, (b) 500 shock waves. Population doubling time was about $10 \mathrm{~h}$ for both control and treated cells.

in the VOL-channel decreased and a second peak due to cell nuclei, cell fragments, and debris appeared. With regard to the number of intact cells in the VOL-channel the proportion of viable cells in the FDA-channel decreased in a dose-dependent manner, accordingly the number of dead cells in the PIchannel increased, which is comparable to the trypan blue measurements. All data in Fig. 8 are related to 10,000 events in the VOL-channel.

Thus, the total amount of viable cells can be calculated from the concentration measurements of intact cells in the Coulter Counter and from the corresponding data in the FDA-channel, as is demonstrated for 500 shock waves (see Fig. 7a): 


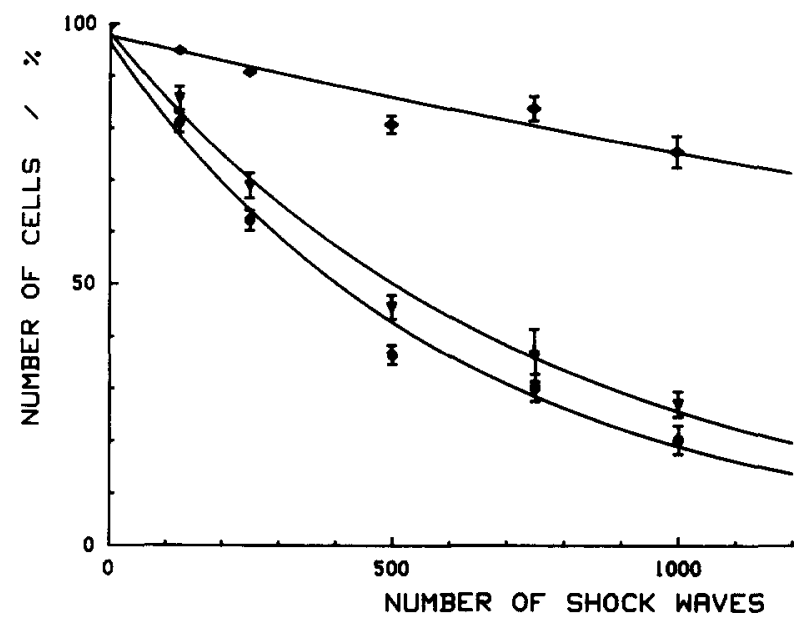

(a)

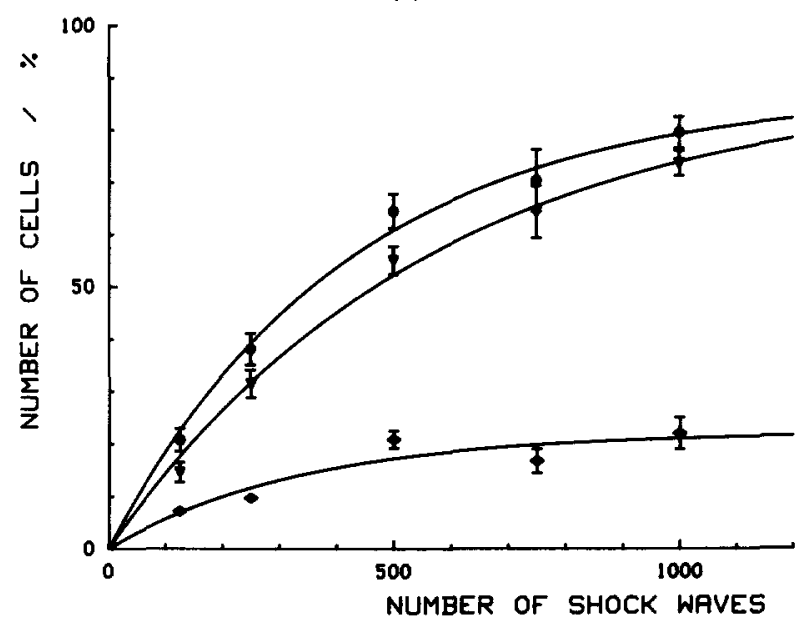

(b)

Fig. 7. Effect of shock waves on L1210 mouse leukemia cells in suspension demonstrated by the decrease of viability (a) and increase of damaged (b) cells. For details see text.

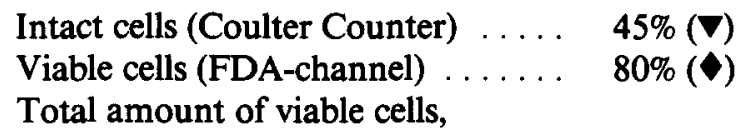
$(45 / 100) \times 80 \ldots \ldots \ldots \ldots \ldots \quad 36 \%(\bullet)$ The control is given by independent measurements of PI stained dead cells (see Fig. 7b)

Nonintact cells (Coulter Counter) . $\quad 55 \%(\nabla)$

Dead cells (PI-channel) ........ 21\%( $\bullet)$

Total amount of dead cells, $[(45 / 100) \times 21]+55$ $64 \%(\odot)$

Analysis of all corrected data revealed a dose-dependent decrease of viable cells $\left(N_{0}=96.4, b\right.$ $=1.64 \cdot 10^{-3}$ ) with a $\mathrm{LD}_{50}$ of 420 shock waves.

Closer inspection of the cell suspensions during shock wave treatment revealed considerable agitation of the cells so that they never settle completely when treated with $1-\mathrm{Hz}$ shock wave pulses. For better dem- onstration of this agitation, cell aggregates (multicell spheroids) were positioned in the target focus, exposed to a single shock wave and photographed with stroboscopic illumination as is shown in Fig. 9. The rapid acceleration of the cells leads to shear forces and causes collisions which damage the cells. These secondary effects can be avoided by immobilizing the L1210 cells in gelatine. Under this condition a dosedependent damage of the cells is no longer detectable (Fig. 10) with the applied techniques.

\section{DISCUSSION}

Shock waves generated in water will proceed unaffected through this and any other medium with the same acoustic impedance. A (partial) reflection will occur when these shock waves hit a medium of different acoustic impedance, e.g., kidney stones. This reflection leads to tension waves at the entry as well as at the exit side of this medium and causes severe destruction, which can also be seen in Fig. 2. Intensity of shock waves will be attenuated by energy loss due to cavitation in the propagation medium (water, tissue).

In a first approximation, cells and tissues have the same acoustic impedance as water and they should therefore remain unaffected when exposed to shock waves. However, shock waves generated by an $18-\mathrm{kV}$ discharge with a frequency of $1 \mathrm{~Hz}$ affect the viability of $\mathrm{L} 1210$ tumor cells in suspension as measured by different experimental approaches. We were able to discriminate between cell fragmentation and defects of the cell membrane permeability. Effects of shock wave treatment on cell morphology were detected by light microscopical histology, ranging from total cell fragmentation to alterations in cell shape such as folding of the plasma membrane which points to osmotic effects as well as swollen and translucent cells indicating a permeabilisation of the plasma membrane. These results correspond well with studies of Russo and coworkers (1987), who reported a cytotoxic effect of shock waves on rat prostatic carcinoma cells in suspensions.

A higher proportion of damaged cells could be observed in L1210 cell suspensions when treated in partially degassed water. Furthermore, with untreated water we observed a wider distribution of shock wave impacts and a smaller crater in platter blocks than after shock wave exposure in partially degassed water. A higher gas concentration in the water bath increases cavitation which absorb energy from the shock waves and dissipate the geometrically defined target focus of the ellipsoid (Heine 1987; 

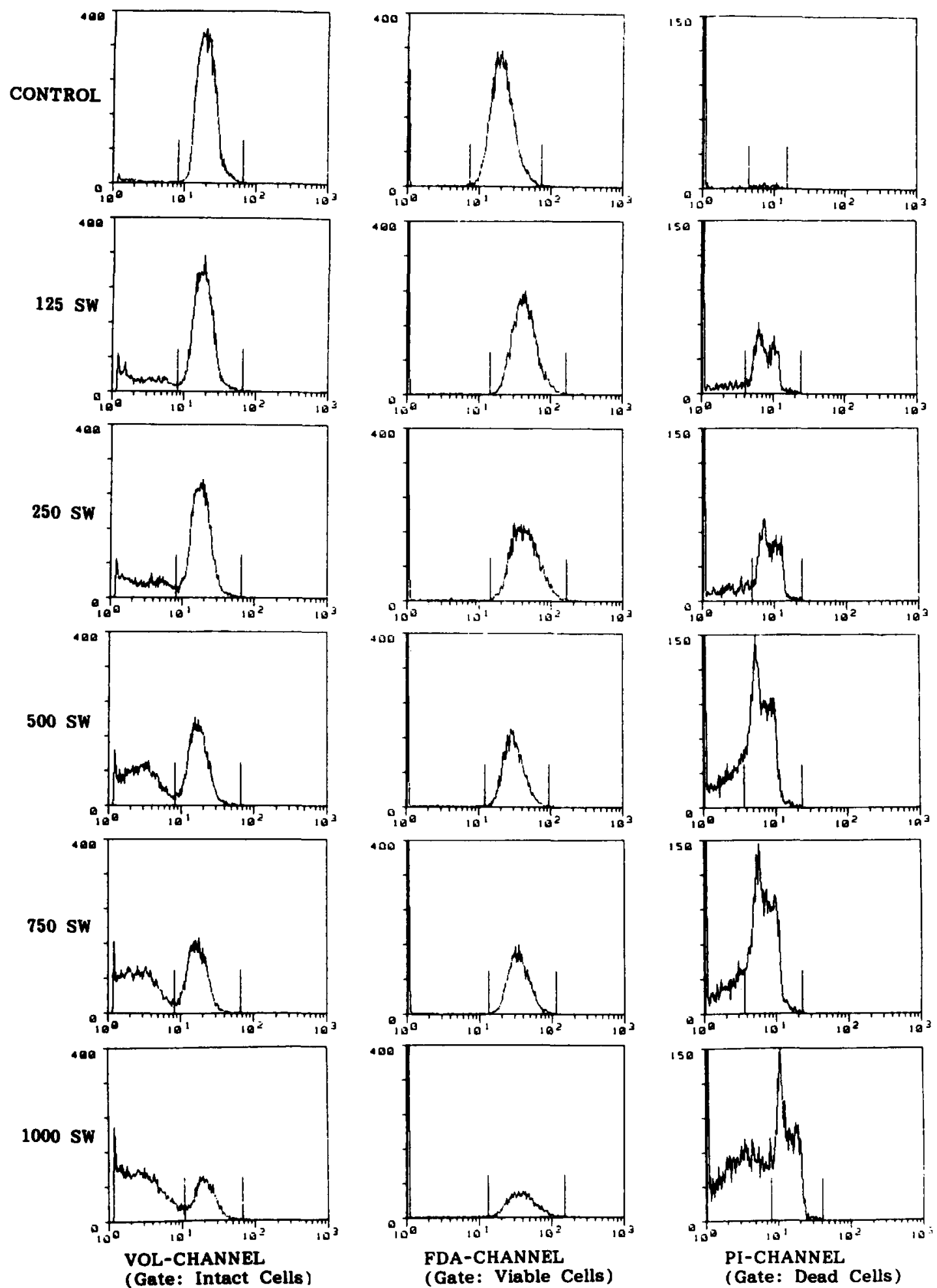

Fig. 8. Flow cytometry measurements of volume, viability and damage of $L 1210$ mouse leukemia cells in suspension after different shock wave exposure.

Müller 1987; Saunders and Coleman 1987). The size of the XL1-target focus with $50 \%$ of the maximum pressure is at least the same as that of our pipette ball which was used to position the cells in the lithotripter and which has a similar acoustic impedance as water. The electrodes' condition, however, had no signif- 


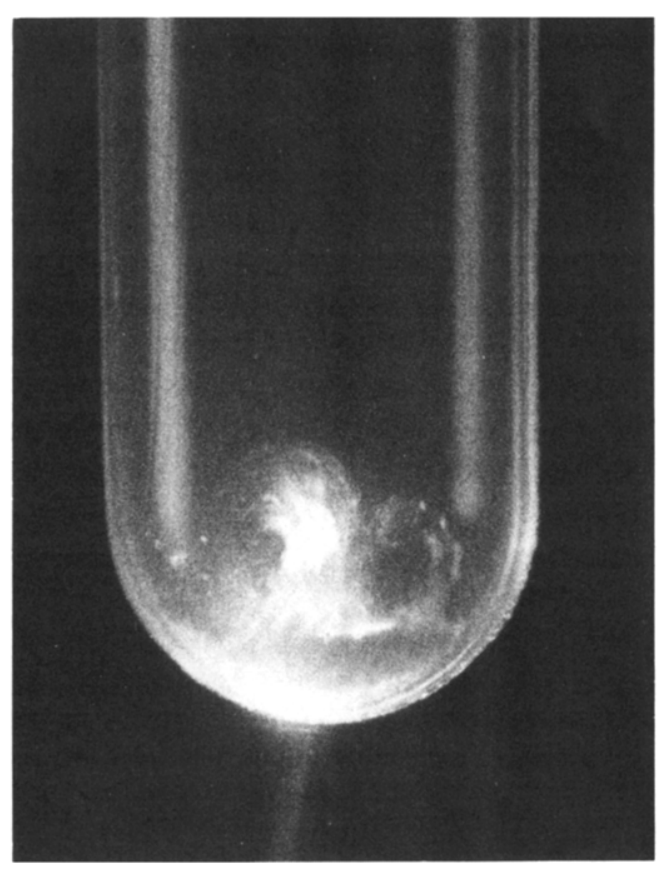

Fig. 9. Multicell spheroids in a polyethylene pipette exposed to a single shock wave. Photographed with stroboscopic illumination.

cant influence on the results. In order to determine the total cell loss due to cell fragmentation during shock wave exposure, we electronically counted cells within a defined volume range before and after treatment with different shock wave doses in a Coulter Counter. With this technique about $50 \%$ cell loss was measured after treatment with 500 shock waves in partially degassed water $(4.3 \mathrm{mg} \mathrm{O} / 1)$ at $37^{\circ} \mathrm{C}$. Information on the surviving cell fraction, however, requires additional investigations, for instance measurements of the cell membranes' integrity. As a common cell viability test the trypan blue dye exclusion is applied (Phillips 1973; Bhuyan et al. 1976). With this method Russo et al. (1986) observed a decrease in viability in shock-wave-exposed suspensions of rat prostatic carcinoma cells: $69 \%$ viability after 800 shock waves and $68 \%$ after 1500 shock waves. The results of this viability test, however, reveal only the proportion of nonviable intact cells and disregard those cells which were completely destroyed (cell debris).

We, therefore, applied flow cytometry which provides simultaneous measurements of three cellular parameters in a large number of cells immediately after shock wave exposure. Thus, we obtained data on the cell volume, the ability to enzymatically hydrolize FDA, and the cell membrane ability to exclude PI. These measurements allowed a discrimina- tion between geometrically intact cells, physiologically active-viable-cells, and seriously damaged-dead-cells. With this method, a dosedependent decrease in cell viability after shock wave exposure of cell suspensions could be observed.

Flow cytometry allowed a rapid and reliable detection of cell damage occurring immediately after shock wave application. Information on long-term effects of shock waves, however, may be detected by an alteration in the cell proliferation. Measurements of the population doubling time of L1210 cells after treatment with 125 and 500 shock waves did not reveal any differences compared with untreated cultures. As can be seen from growth curves of cultures exposed to 125 and 500 shock waves, however, a lag phase before entering the exponential growth phase is exhibited. This can be explained by the inability to proliferate for a fraction of geometrically intact cells. For shock wave treatment the cells have been taken from exponentially growing cultures as can be seen from the controls (Fig. 6). Assuming that only a minor fraction is damaged to that extent that a proliferation is impossible, this fraction can be obtained by extrapolating the logarithmic growth phase to the start point of the culture (time zero). This reveals that after 125 as well as after 500 shock waves about $20 \%$ of the inoculated intact cells were unable to proliferate. Interestingly, these figures correspond very well with the fraction of intact cells which were analyzed as dead in the PI channel of the FACS-Analyzer. The majority of cells, however, exhibited an unaffected proliferation, thus excluding severe damages of cellular functions.

In contrast, Russo et al. (1986) reported for shock-wave-exposed tumor cells a significant de-

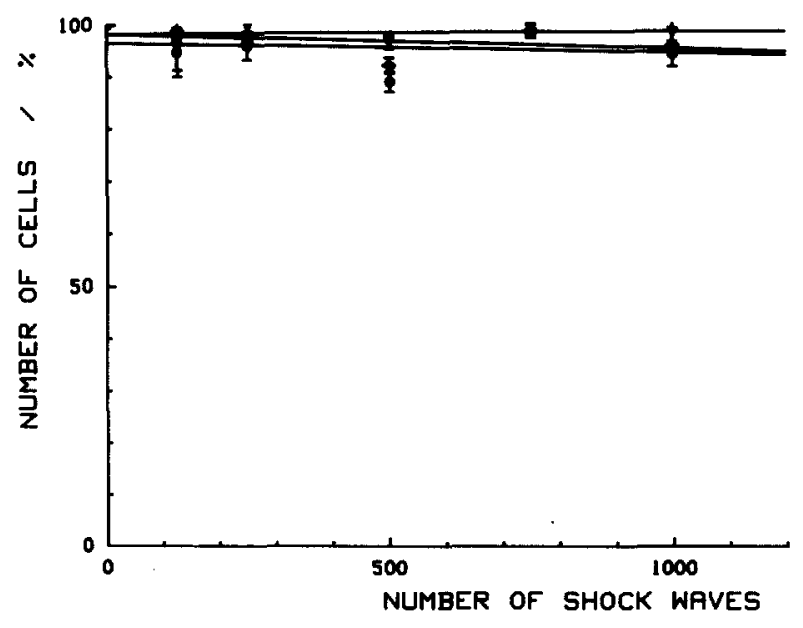

Fig. 10. Effect of shock waves on L1210 mouse leukemia cells immobilized in gelatine. Up to 1000 shock waves the dose dependence is negligible. 
crease in their ability to form colonies. They used a quite different viability assay, the soft agar colony formation test, which runs for 14 days. Furthermore, different cell lines may exhibit a different degree of sensitivity to shock wave treatment, as was mentioned by Russo et al. (1986) for a human melanoma, which was more sensitive to shock waves than rat carcinoma cells.

During the last years the number of shock waves applied for kidney stone destruction has increased considerably. The first 945 patients were treated with an average of 978 shock waves (Chaussy et al. 1984) and this number has increased to an average of about 1300 shock waves (Chaussy et al. 1986c; Schmidt and Eisenberger 1987). Shock waves caused haemorrhages in kidneys, but this effect, however, is considered as a minor injury and even 3000 shock waves are considered as tolerable (Delius et al. 1988).

The high extent of cell damage with a low number of shock waves in our study compared to clinical application cannot be explained by a higher sensitivity of L1210 cells to shock waves. In our experiments as well as in some other reports (Chaussy et al. 1986a, b; Russo et al. 1986, 1987) the cells were exposed to shock waves as suspension, an experimental condition which cannot be compared with in vivo conditions. In fluids shock waves may cause cavitation, which vigorously agitate the cells and expose them to shear forces. Furthermore, the focusing of shock waves locally accelerates the fluid and forms jets (Müller 1987) which again vigorously agitates the cells as can be judged from Fig. 9. As we have demonstrated, the observed cell damages must be attributed to these secondary effects which occur only with cells in suspension and can be avoided by their immobilisation. With respect to acoustic impedance polymerized gelatine behaves similarly as solid tissue which is unaffected by shock wave treatment (Chaussy et al. 1986c).

On the other hand, kidney damage was reported after in vivo treatment with shock waves. Interestingly they were always connected with the microvasculature (Brendel et al. 1987). Haemorrhages in the inner and outer renal capsule (Delius et al. 1988) were observed as well as shock-wave-caused bleedings in the lungs of beagles when gallstones were destroyed (Delius et al. 1987). These findings indicate that in vivo cellular damage will occur preferentially in or at the vascular system where a fluid interacts with shock waves. Whether these damages must be attributed to cavitation (Brendel et al. 1987; Carstensen 1987; Coleman et al. 1987b; Delius and Brendel 1988) and/or shear forces (Dunn 1985) caused by the acceleration of the cells will be investigated.
Preliminary experiments with cells grown as three-dimensional multicell spheroids embedded in an agar gel prior to the shock wave exposure did not show any destruction on the light microscopical level (Bräuner et al. 1988). Comparative electron microscopical and physiological investigations on suspended and immobilized single cell cultures as well as multicell spheroids are in progress and will show if shock waves cause minor or transient alterations in immobilized cells.

Acknowledgment-This work was supported by Dornier Medizintechnik and Bundesministerium für Forschung und Technologie. We thank Ms. Ulrike Reber and Ms. Beate Rehkopf for expert technical assistance.

\section{REFERENCES}

Bhuyan, B. K.; Loughman, T. J.; Fraser, T. J.; Day, K. J. Comparison of different methods of determing cell viability after exposure to cytotoxic compounds. Exp. Cell Res. 97:275-280; 1976.

Brendel, W.; Enders, G. Shock waves for gallstones: animal studies. Lancet I: $1054 ; 1983$.

Brendel, W.; Delius, M.; Goetz, A. Effect of shock waves on the microvasculature. Prog. Appl. Microcirc. 12:41-50; 1987.

Bräuner, Th.; Brümmer, F.; Hülser, D. F. Effects of lithotriptergenerated high energy shock waves on multicell spheroids in suspension or immobilized in agar. Cytotechnology (Suppl.) August:44; 1988.

Brümmer, F.; Bräuner, Th.; Brenner, J.; Hülser, D. F. Effects of Lithotripter-generated shock waves on L1210 mouse Leukemia cells detected by Flow Cytometry. Eur. J. Cell Biol. 46:12; 1988.

Carstensen, E. L. Acoustic cavitation and the safety of diagnostic ultrasound. Ultrasound in Med. \& Biol. 13:597-606; 1987.

Chaussy, Ch.; Schmiedt, E.; Jocham, D.; Brendel, W.; Forssmann, B.; Walther, V. First clinical experiences with extracorporeally induced destruction of kidney stones by shock waves. J. Urol. 127:417-420; 1982.

Chaussy, Ch.; Schmiedt, E.; Jocham, D.; Schüller, J.; Brandl, H.; Liedl, B. Extracorporeal shock-wave lithotripsy (ESWL) for treatment of urolithiasis. Urology 23:59-66; 1984.

Chaussy, Ch. G.; Randazzo, R. F.; Fuchs, G. J. The effects of extracorporeal shock waves on FANFT bladder tumors in C3H/He mice. J. Urol. 135:289A; 1986a.

Chaussy, Ch. G.; Randazzo, R. F.; Fuchs, G. J. The effects of extracorporeal shock waves on human renal carcinoma cells and normal human embryonic kidney cells. J. Urol. 135:320A; 1986b.

Chaussy, Ch.; Schmiedt, E.; Jocham, D.; Fuchs, G.; Brendel, W.; Forssmann, B.; Hepp, W. In: Chaussy, Ch., ed. Extracorporeal shock wave lithotripsy. Basel: Karger; 1986c.

Chen, T. R. In situ detection of mycoplasma contamination in cell cultures by fluorescent Hoechst 33258 stain. Exp. Cell Res. 104:255-262; 1977.

Coleman, A. J.; Saunders, J. E.; Preston, R. C.; Bacon, D. R. Pressure waveforms generated by a Dornier extracorporeal shock-wave lithotripter. Ultrasound in Med. \& Biol. 13:651$657 ; 1987 \mathrm{a}$.

Coleman, A. J.; Saunders, J. E.; Crum, L. A.; Dyson, M. Acoustic cavitation generated by an extracorporeal shockwave lithotripter. Ultrasound in Med. \& Biol. 13:69-76; 1987b.

Coulter, W. H. High speed automatic blood cell counter and cell size analyzer. Proc. Natl. Elec. Conf. 12:1034-1043; 1956.

Delius, M. Extracorporeal shock-wave lithotripsy of Gallstones. In: Baethmann, A.; Messmer, K., eds. Surgical research: Recent concepts and results. Heidelberg. Berlin: Springer Verlag; 1987:77-81.

Delius, M.; Enders, G.; Heine, G.; Stark, J.; Remberger, K.; Brendel, W. Biological effects of shock waves: lung hemorrhage by 
shock waves in dogs-pressure dependence. Ultrasound in Med. \& Biol. 13:61-67; 1987.

Delius, M.; Enders, G.; Xuan, Z.; Liebich, H.-G.; Brendel, W. Biological effects of shock waves: kidney damage by shock waves in dogs-dose dependence. Ultrasound in Med. \& Biol. 14:117-122; 1988.

Delius, M.; Brendel, W. A mechanism of gallstone destruction by extracorporeal shock waves. Naturwissenschaften 75:200-201; 1988.

Dunn, F. Cellular inactivation by heat and shear. Radiat. Environ. Biophys. 24:131-139; 1985.

Eisenberger, F. Fortschritte in der extrakorporalen Stosswellenlithotripsie. Historie, gegenwärtige Gerätephilosophie und klinische Daten. Biomed. Technik. 33:11-12; 1988.

Eisenberger, F.; Rassweiler J. Extrakorporale Stoßwellenlithotripsie in Wandel. Akt. Urol. 17:229-233; 1986.

Heine, G. Alternative Stoßwellenerzeugungsverfahren. In: Ziegler, M., ed. Die extrakorporale und laserinduzierte Stoßwellenlithotripsie bei Harnund Gallensteinen. Berlin: Springer Verlag; 1987:1-19.

Hutchinson, D. J.; Ittensohn, O. L.; Bjerregaard, M. R. Growth of L1210 mouse leukemia cells in vitro. Exp. Cell Res. 42:157$170 ; 1966$.

Kaude, J. V.; Williams, C. M.; Millner, M. R.; Scott, K. N.; Finlayson, B. Renal morphology and function immediately after extracorporeal shock-wave lithotripsy. Am. J. Roent. 145:305$313 ; 1985$.

Kishimoto, T.; Yamamoto, K.; Sugimoto, T.; Yoshihara, H.; Maekawa, M. Side effects of extracorporeal shock-wave exposure in patients treated by extracorporeal shock-wave lithotripsy for upper urinary tract stone. Eur. Urol. 12:308-313; 1986.

Krishan, A. Rapid flow cytofluorometric analysis of mammalian cell cycle by propidium iodide staining. J. Cell Biol. 66:188193; 1975.

Lienert, G. A. Verteilungsfreie Methoden in der Biostatistik. Band I. Meisenheim am Glan: Verlag Anton Hain; 1973.
Lorenz, R. J. Grundbegriffe der Biometrie. Stuttgart: Gustav Fischer Verlag; 1984.

Müller, M. Stoßwellenfokussierung in Wasser. RWTH Aachen; 1987. Ph.D. Thesis.

Phillips, H. J. Dye exclusions test for cell viability. In: Kruse, P. F. et al., eds. Tissue culture New York: Academic Press; 1973:406-408.

Richardson, K. C.; Jarret, L.; Finke, F. H. Embedding in epoxy resins for ultrathin sectioning in electron microscopy. Stain Technol. 35:313-323; 1960.

Rotman, B.; Papermaster, B. W. Membrane properties of living mammalian cells as studied by enzymatic hydrolysis of fluorogenic esters. Proc. Natl. Acad. Sci. 55:134-141; 1966.

Russo, P.; Stephenson, R. A.; Mies, C.; Huryk, R.; Heston, W. D. W.; Melamed, M. R.; Fair, W. R. High energy shock waves suppress tumor growth in vitro and in vivo. J. Urol. 135:626-628; 1986.

Russo, P.; Mies, C.; Huryk, R.; Heston, W. D. W.; Fair, W. R. Histopathologic and ultrastructural correlates of tumor growth suppression by high energy shock waves. J. Urol. 137:338-341; 1987.

Sasaki, D. T.; Dumas, S. E.; Engleman, E. G. Discrimination of viable and nonviable cells using propidium iodide in two color immunofluorescence. Cytometry 8:413-420; 1987.

Sauerbruch, T.; Delius, M.; Paumgartner, G.; Holl, J.; Wess, O.; Weber, W.; Hepp, W.; Brendel, W. Fragmentation of gallstones by extracorporeal shock waves. N. Engl. J. Med. 314:818-822; 1986.

Saunders, J. E.; Coleman, A. J. Physical characteristics of Dornier extracorporeal shock-wave lithotriptor. Urology 24:506-509; 1987.

Schmidt, A.; Eisenberger, F. Extrakorporale Stoßwellenlithotripsie am Beispiel ESWL Dornier. Krankenpflege-Journal 10:55-57; 1987.

Wilton-Smith, P. Sending cells safely through the mail. Trends in Biotechnology $1: 101 ; 1983$. 